\title{
Aloe-emodin suppresses esophageal cancer cell TE1 proliferation by inhibiting AKT and ERK phosphorylation
}

\author{
XIAOBIN CHANG $^{1 *}$, JIMIN ZHAO $^{1 *}$, FANG TIAN $^{1 *}$, YANAN JIANG $^{1}$, JING LU $^{1}$, \\ JUNFEN MA $^{1}$, XIAOYAN ZHANG ${ }^{1}$, GUOGUO JIN ${ }^{1}$, YOUTIAN HUANG ${ }^{1}$, \\ ZIGANG DONG $^{1,2}$, KANGDONG LIU $^{1,3}$ and ZIMING DONG ${ }^{1}$
}

${ }^{1}$ Department of Pathophysiology, School of Basic Medical Sciences, Zhengzhou University, Zhengzhou, Henan 450001, P.R. China; ${ }^{2}$ Department of Chemical Prevention, The Hormel Institute, University of Minnesota, Austin, MN 55912, USA; ${ }^{3}$ Department of Science Research, The Affiliated Cancer Hospital, Zhengzhou University, Zhengzhou, Henan 450003, P.R. China

Received May 8, 2015; Accepted July 1, 2016

DOI: $10.3892 / \mathrm{ol} .2016 .4910$

\begin{abstract}
Aberrant AKT and extracellular signal-regulated kinase (ERK) activation is often observed in various human cancers. Both AKT and ERK are important in the phosphoinositide 3-kinase/AKT and mitogen-activated protein kinase kinase/ERK signaling pathways, which play vital roles in cell proliferation, differentiation and survival. Compounds that are able to block these pathways have therefore a promising use in cancer treatment and prevention. The present study revealed that AKT and ERK are activated in esophageal cancer TE1 cells. Aloe-emodin, an anthraquinone present in aloe latex, can suppress TE1 cell proliferation and anchor-independent cell growth. Aloe-emodin can also reduce the number of TE1 cells in S phase. Protein analysis indicated that aloe-emodin inhibits the phosphorylation of AKT and ERK in a dose-dependent manner. Overall, the present data indicate that aloe-emodin can suppress TE1 cell growth by inhibiting AKT and ERK phosphorylation, and suggest its clinical use for cancer therapy.
\end{abstract}

\section{Introduction}

Esophageal cancer (EC) is one of the most common cancers in the world (1). Esophageal squamous cell carcinoma (ESCC) and esophageal adenocarcinoma (EAC) are the two main types

Correspondence to: Professor Ziming Dong or Professor Kangdong Liu, Department of Pathophysiology, School of Basic Medical Sciences, Zhengzhou University, No. 100 Kexue Avenue, Zhengzhou, Henan 450001, P.R. China

E-mail: dongzm@zzu.edu.cn

E-mail:kdliu@zzu.edu.cn

*Contributed equally

Key words: esophageal cancer, aloe-emodin, signal transduction pathway of EC (2), with ESCC being the main form of EC in Asian countries, and EAC being the most common type of EC in Western countries (3). The incidence of EC is increasing worldwide (4). In the USA in 2012, 17,460 patients were diagnosed with EC, and 15,070 patients succumbed to the disease (5). Upon initial diagnosis, the majority of EC patients already present with metastasis, which results in poor prognosis $(6,7)$.

Accumulating evidence indicates that numerous molecular changes are associated with EC tumorigenesis, including epidermal growth factor receptor (EGFR) amplification, phosphoinositide 3-kinase, catalytic subunit alpha (PIK3CA) amplification and mutation (8-10), and phosphatase and tensin homolog (PTEN) mutation or loss $(11,12)$. Alteration of these molecular events contributes to downstream pathway activation (8-12). The phosphoinositide 3-kinase (PI3K)/AKT and mitogen-activated protein kinase kinase (MEK)/ERK signaling pathways are two important pathways that can be activated by EGFR amplification and PTEN loss, which may ultimately lead to tumorigenesis (13). ERK is a downstream component of an evolutionarily conserved signaling module that is activated by Raf serine/threonine kinases (14). Raf is activated by growth factor stimulation, eventually leading to the activation of ERK (14). ERK then can mediate cell proliferation and oncogenesis through downstream targeting (15). ERK can activate the pro-apoptotic protein B-cell lymphoma-2 (Bcl-2)-associated death promoter (BAD) at Ser112 and phosphorylate the transcription factor cyclic adenosine monophosphate response element-binding protein (CREB) at Ser133 to promote cell survival by activating the ribosomal S6 kinase (RSK) family of serine/threonine kinases (16). Previously, inhibitors targeting this pathway were developed and tested in clinical trials $(15,17)$ with certain success.

Tumorigenesis frequently occurs during PI3K/AKT signal pathway activation following EGFR amplification and PTEN loss (18). Activation of AKT results from Thr308 phosphorylation by 3-phosphoinositide-dependent kinase 1 (PDK1) and Ser473 phosphorylation by mechanistic target of rapamycin complex 2 (mTORC2) (18). AKT regulates CREB activity $(19,20)$ by phosphorylating CREB at Ser133, which 
induces the binding of accessory proteins, thereby regulating anti-apoptotic genes, including Bcl-2 and myeloid cell leukemia $1(21,22)$. AKT can suppress mouse double minute 2 homolog (MDM2) self-ubiquitination, thereby inhibiting p53-mediated apoptosis (23). AKT also promotes the cell cycle by phosphorylating $\mathrm{p} 21^{\text {Waf1/Cipl }}$, also known as cyclin-dependent kinase inhibitor 1 or CDK-interacting protein 1, at Thr145 (24). In addition, AKT directly controls the activation of glycogen synthase kinase (GSK) $3 \beta$. which phosphorylates cyclin D1 at Thr286 (25) and Myc at Thr58 (26). GSK3 $\beta$ promotes the nuclear export and ubiquitin-pathway degradation of AKT, which could in turn regulate the cell cycle by regulating GSK $3 \beta$ activity (25). Therefore, blocking the activation of PI3K/AKT signaling may be a promising strategy for cancer treatment.

Aloe-emodin has anti-proliferative effects and induces cellular apoptosis (27-30). Aloe-emodin has anti-cancer activity in neuroectodermal tumors (31), nasopharyngeal carcinoma (32), lung squamous cell carcinoma (33), hepatoma cells (34), gastric cancer (35) and prostate cancer (36). Aloe-emodin induces apoptotic cell death by oxidative stress and sustained c-Jun N-terminal kinase (JNK) activation (37). Previous studies have demonstrated that aloe-emodin induces cell death through S-phase arrest in human tongue squamous cancer SCC-4 cells (38). A previous study by the present authors also indicated that mTORC2 is a target of aloe-emodin, and aloe-emodin can strongly inhibit the AKT activation caused by PTEN loss (36). Aloe-emodin is a natural compound from aloe or Rheum palmatum $(39,40)$. The present study aimed to determine the efficacy of aloe-emodin in the treatment of EC.

The present results demonstrate that both ERK and AKT are activated in EC cells. Aloe-emodin can suppress the proliferation and anchor-independent cell growth of the EC cell line TE1. Western blot data revealed that aloe-emodin inhibits both AKT and ERK phosphorylation and their downstream activation. The inhibition of these pathways results in cell cycle arrest at $\mathrm{S}$ phase and decreased cyclin D1 transcription. These results suggest that aloe-emodin could prevent and even reverse the development of EC, thus identifying it as a candidate compound for EC chemoprevention.

\section{Materials and methods}

Materials. Aloe-emodin ( $>95 \%$ purity) was purchased from Sigma-Aldrich (St. Louis, MO, USA). Other chemical reagents, including Tris, $\mathrm{NaCl}$, acrylamide, glycine and sodium dodecyl sulfate (SDS), were purchased from Sigma-Aldrich or Fluka (Sigma-Aldrich). AKT [rabbit polyclonal immunoglobulin G (IgG); sc-8312], p-AKT (mouse monoclonal $\mathrm{IgG}_{1}$; sc-293125), ERK (rabbit polyclonal IgG; sc-94) and p-ERK (rabbit polyclonal IgG; sc-23759) primary antibodies, and horseradish peroxidase (HRP)-conjugated goat anti-rabbit IgG (sc-2004) and HRP-conjugated rabbit anti-mouse IgG (sc-358914) secondary antibodies were obtained from Santa Cruz Biotechnology, Inc. (Dallas, TX, USA). $\alpha$-tubulin (rabbit polyclonal; \#2148) antibody was obtained from Cell Signaling Technology, Inc. (Danvers, MA, USA).

Cell culture. The esophageal cancer cell lines TE1 and KYSE140 were purchased from Nanjing KeyGen Biotech
Co., Ltd. (Nanjing, China). Eca109 and EC9706 cells were provided by the State Key Laboratory of Molecular Oncology, Chinese Academy of Medical Science (Shanghai, China). TE1 cells were cultured in Dulbecco's modified Eagle's medium (DMEM)-high glucose (HyClone; GE Healthcare Life Sciences, Logan, UT, USA) containing $10 \%$ fetal bovine serum (FBS) (Gibco; Thermo Fisher Scientific, Inc., Waltham, MA, USA), $10 \mathrm{IU}$ penicillin/ml and $10 \mathrm{IU}$ streptomycin $/ \mathrm{ml}$ at $37^{\circ} \mathrm{C}$ in a humidified incubator with $5 \% \mathrm{CO}_{2}$.

Cell counting kit-8 (CCK-8) assay. TE1 cells $\left(2 \times 10^{4}\right)$ were seeded into 96 -well plates in $100 \mu \mathrm{l}$ of $10 \%$ FBS-DMEM, and incubated in a $37^{\circ} \mathrm{C}, 5 \% \mathrm{CO}_{2}$ incubator overnight. The cells were treated with increasing doses of aloe-emodin $(1,5,10$, 25 and $50 \mu \mathrm{M}$ ), and cytotoxicity was analyzed at $24 \mathrm{~h}$ and 48 h using a CCK-8 (Beyotime Institute of Biotechnology, Haimen, China) according to the manufacturer's protocol. TE1 cells $\left(5 \times 10^{3}\right)$ were seeded in 96-well plates in $100 \mu \mathrm{l}$ of $10 \%$ FBS-DMEM and cultured in a $37^{\circ} \mathrm{C}, 5 \% \mathrm{CO}_{2}$ incubator. After $12 \mathrm{~h}$, the medium was changed for medium containing different concentrations of aloe-emodin $(0,2.5,5,10$ and $20 \mu \mathrm{M})$. Cells were cultured for an additional 24, 48, 72 and $96 \mathrm{~h}$, and $10 \mu \mathrm{l}$ of CCK-8 was then added to each well. The cells were incubated for $2 \mathrm{~h}$ and the absorbance was measured at $450 \mathrm{~nm}$.

Soft agar assay. The soft agar assay was performed in 6-well plates containing two layers of agar (Bacto Agar; BD Biosciences, Franklin Lakes, NJ, USA) and different concentrations of aloe-emodin $(0,2.5,5,10$ and $20 \mu \mathrm{M})$. The bottom layer consisted of $0.5 \%$ agar in $1 \mathrm{ml}$ of basal medium Eagle (BEM; Sigma-Aldrich) with $10 \%$ FBS. The top layer consisted of $0.33 \%$ agar in $1 \mathrm{ml}$ of BEM with $10 \%$ FBS containing $8 \times 10^{3}$ TE1 cells. The TE1 cells embedded in agar were incubated in a $37^{\circ} \mathrm{C}$ humid incubator for 14 days, and colonies were imaged using a microscope with the aid of Image-Pro Plus software (version 6; Media Cybernetics, Inc., Rockville, MD, USA) and MicroPublisher 5.0 RTV camera (Olympus Corporation, Tokyo, Japan).

Cell cycle analysis. For flow cytometric analysis of cell cycle, TE1 cells $\left(1.5 \times 10^{6}\right)$ were seeded into a $60-\mathrm{mm}$ dish. After $12 \mathrm{~h}$ of culture, the cells were washed three times with Dulbecco's phosphate-buffered saline (DPBS, pH 7.2). The cells were next cultured for $48 \mathrm{~h}$ in DMEM without FBS. Then, the FBS-free DMEM was removed, and different concentrations of aloe-emodin $(0,2.5,5,10$ and $20 \mu \mathrm{M})$ in DMEM containing $10 \%$ FBS were added to each dish. After culturing for additional $48 \mathrm{~h}$, the cells were trypsinized, washed with ice-cold DPBS and fixed with ice-cold $70 \%$ ethanol at $-20^{\circ} \mathrm{C}$ overnight. Cells were then washed twice with DPBS, incubated with $0.5 \mathrm{mg} / \mathrm{ml} \mathrm{RNase}$ A and $200 \mu \mathrm{g} / \mathrm{ml}$ propidium iodide in DPBS at room temperature for $30 \mathrm{~min}$ in the dark, and subjected to flow cytometry using a FACSCalibur flow cytometer (BD Biosciences). The percentages of cells in different cell cycle phases (G0/G1, S or G2/M) were calculated.

Western blotting. A total of $1.5 \times 10^{6} \mathrm{TE} 1$ cells were seeded and cultured in a $10-\mathrm{cm}$ dish for $24 \mathrm{~h}$. The cells were treated with various concentrations of aloe-emodin $(0,2.5,5,10$ and 
$20 \mu \mathrm{M}$ ) for additional $24 \mathrm{~h}$. The cells were then harvested, and cell lysates were collected in modified radioimmunoprecipitation assay buffer (50 mM Tris base, 1\% NP-40, 0.25\% superoxide dismutase, $150 \mathrm{mM} \mathrm{NaCl}, 1 \mathrm{mM}$ ethylenediaminetetraacetic acid and $0.1 \% \mathrm{SDS}$ ). A total of $50 \mu \mathrm{g}$ proteins were subjected to $12 \%$ SDS-polyacrylamide gel electrophoresis. The nitrocellulose membranes (Hybond-c pure; GE Healthcare Life Sciences, Chalfont, UK) with transferred protein were incubated with a specific primary antibody [anti-AKT (1:200), p-AKT (1:200), ERK (1:200), p-ERK (1:200) or $\alpha$-tubulin $(1: 1,000)]$ at $4{ }^{\circ} \mathrm{C}$ overnight, followed by incubation with the appropriate secondary antibody $(1: 1,000)$ for $2 \mathrm{~h}$ at room temperature. Protein bands were detected with an enhanced chemiluminescence (ECL) kit (Beyo ECL Plus; Beyotime Institute of Biotechnology) after hybridization with a specific secondary antibody.

Cyclin D1 luciferase assay. TE1 cells $\left(600 \times 10^{3}\right.$ cells/well) were seeded and cultured in 24-well plates for $12 \mathrm{~h}$, prior to be transfected with $400 \mathrm{ng}$ of the pGL4.29/Luc/Cyclin D1 reporter gene plasmid (generously donated by Dr Chris Albanese, Department of Developmental and Molecular Biology, Albert Einstein Cancer Center, Albert Einstein College of Medicine, New York, NY, USA) via a DNA transfection method (jetPRIME ${ }^{\circledR}$, Polyplus-transfection ${ }^{\circledR}$ SA, Illkirch, France). This reporter gene was constructed from the $-1,715$ to +134 region of the human cyclin D1 promoter (41). The medium was replaced with medium containing different aloe-emodin concentrations $(0,2.5,5,10$ and $20 \mu \mathrm{M})$ after $6 \mathrm{~h}$ transfection. For luciferase detection, the cells were incubated for another $24 \mathrm{~h}$. Luciferase assays were performed with the Dual-Luciferase $^{\circledR}$ Reporter (DLR ${ }^{\mathrm{TM}}$ ) Assay System (Promega Corporation, Madison, WI, USA) according to the manufacturer's protocol. Detection was conducted with the Centro LB 960 microplate luminometer (Berthold Technologies GmbH \& Co. KG, Bad Wildbad, Germany), and the data were calculated as the mean of three independent experiments.

Statistical analysis. All the data were reported as means \pm standard error or standard deviation, as calculated with the statistical software SPSS version 17.0 (SPSS, Inc., Chicago, IL, USA). Single factor analysis of variance was used for statistical analysis. $\mathrm{P}<0.05$ was considered to indicate a statistically significant difference.

\section{Results}

$A K T$ and ERK are activated in EC cell lines. Since the MEK/ERK and PI3K/AKT signaling pathways are important in tumorigenesis, the level of activation of these pathways in EC cells was investigated. Cell lysates of different human EC cell lines were collected and subjected to western blot analysis to detect AKT and ERK phosphorylation. AKT phosphorylation at Ser473 was detected in Eca109, TE1 and KYSE140 cells. ERK phosphorylation was detected in Eca109, TE1 and KYSE140 cells. Phosphorylation could not be detected in either AKT or ERK in the EC9706 cell line (Fig. 1).

Aloe-emodin suppresses TE1 cell proliferation and anchor-independent cell growth. Aloe-emodin is a substance

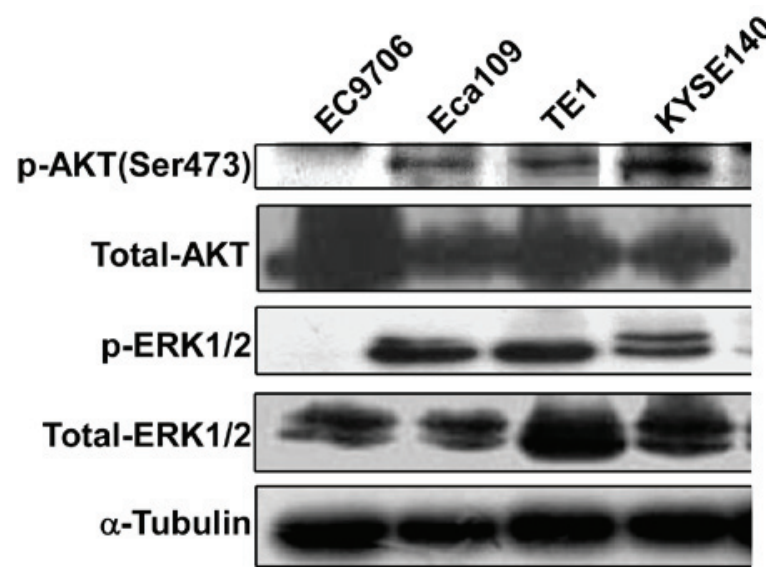

Figure 1. AKT and ERK were activated in EC cell lines. Four human EC cell lines were cultured, and cell lysates were harvested. A total of $50 \mu \mathrm{g}$ of cell lysates of each cell line were subjected to western blot analysis. The phosphorylation of AKT and ERK was evaluated. Representative data of three independent experiments are shown. ERK, extracellular-signal regulated kinase; EC, esophageal cancer; p-, phosphorylated.

derived from aloe or Rheum palmatum that is effective at suppressing cancer cell growth in gastric cancer, prostate cancer and colon cancer cells (Fig. 2A) $(42,43)$. To investigate the degree to which aloe-emodin can suppress EC cell proliferation, TE1 cell growth and anchor-independent cell growth was examined. In the cytotoxicity assay, $90 \%$ of the cells survived after treatment with $20 \mu \mathrm{M}$ aloe-emodin for $48 \mathrm{~h}$ (Fig. 2B). To investigate the level to which aloe-emodin can inhibit TE1 cell proliferation, 2.5,5,10 and $20 \mu \mathrm{M}$ aloe-emodin was added to the medium of TE1 cells, and CCK-8 assay was performed. The data indicated that aloe-emodin suppressed TE1 cell proliferation in a dose-dependent manner (Fig. 3A). An anchor-independent cell growth assay was performed on TE1 cells in the presence of aloe-emodin. The results indicated that aloe-emodin could suppress colony formation of TE1 cells in a dose-dependent manner (Fig. 3B).

Aloe-emodin inhibits AKT and ERK activity. Aloe-emodin was used to inhibit the ERK and AKT-related signaling pathways activated in TE1 cells. The western blot data indicated that aloe-emodin inhibited the phosphorylation of AKT at Ser473 (Fig. 4A). Downstream of AKT, Ser9 phosphorylation of GSK3 $\beta$ also decreased in a dose-dependent manner. In addition, the phosphorylation of ERK and its downstream target, RSK2, were also investigated. The results indicated that the phosphorylation of ERK at Thr202/Tyr204, RSK2 at Ser360 and CREB at Ser133 was also inhibited by aloe-emodin treatment (Fig. 4B).

Aloe-emodin inhibits TE1 cell growth by decreasing the number of cells in $S$ phase. To investigate the extent to which the aloe-emodin-mediated TE1 cell growth was associated with cell cycle arrest, cell cycle analysis was performed. The data revealed that treatment with increasing concentrations of aloe-emodin for $48 \mathrm{~h}$ resulted in a dose-dependent decrease in the number of cells in $\mathrm{S}$ phase (Fig. 5A).

Aloe-emodin inhibits cyclin D1 expression in TE1 cells. AKT and its downstream kinase GSK $3 \beta$ regulate cyclin 
A<smiles>O=C1c2cccc(O)c2C(=O)C2C(O)=CC(CO)=CC12</smiles>

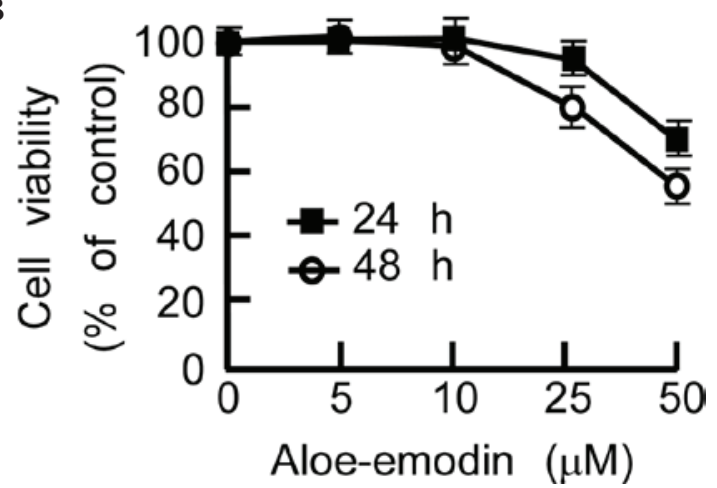

Figure 2. (A) Chemical structure of aloe-emodin. (B) Toxicity of aloe-emodin in TE1 cells. TE1 cells $\left(2 \times 10^{4}\right)$ were seeded into 96 -well plates in $100 \mu 1$ of $10 \%$ fetal bovine serum-Dulbecco's modified Eagle medium, and incubated in a $37^{\circ} \mathrm{C}, 5 \% \mathrm{CO}_{2}$ incubator overnight. The cells were treated with increasing doses of aloe-emodin $(1,5,10,25$ and $50 \mu \mathrm{M})$, and cytotoxicity was analyzed at the indicated times using a Cell Counting Kit-8 (Beyotime Institute of Biotechnology, Haimen, China) according to the manufacturer's protocol.
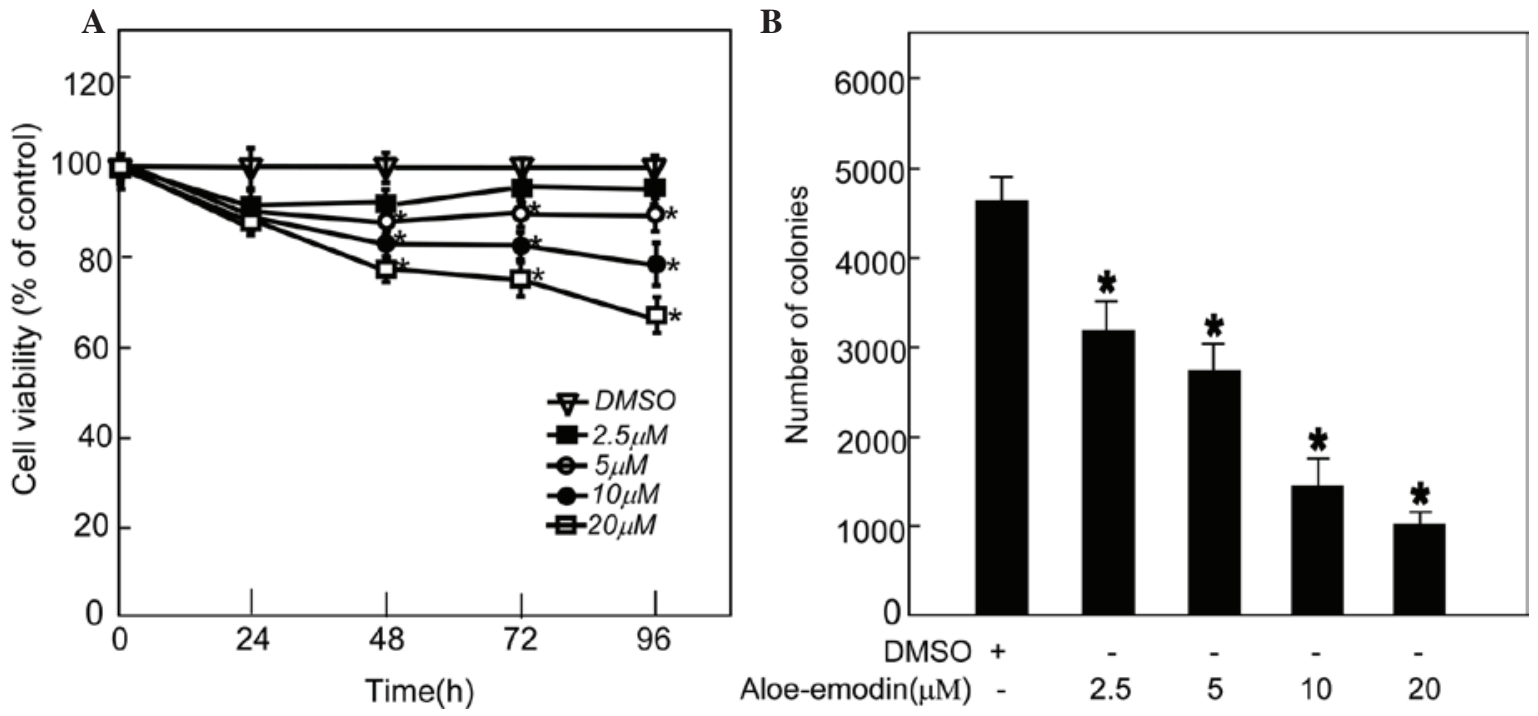

Figure 3. AE suppresses TE1 cell proliferation and anchor-independent cell growth. TE1 cells $\left(5 \times 10^{3}\right)$ were treated with different concentrations of AE. (A) AE significantly inhibited cell proliferation. Absorbance was measured at 24, 48, 72 and $96 \mathrm{~h}$ by Cell Counting Kit- 8 , as described in Materials and methods. Data are shown as means $\pm \mathrm{SD}($ ( $\mathrm{P}<0.05$ vs. untreated control, $\mathrm{n}=3$ ). (B) AE significantly suppressed anchor-independent cell growth of TE1 cells. Colonies were counted, and data are shown as means $\pm \mathrm{SD}\left({ }^{*} \mathrm{P}<0.05\right.$ vs. untreated control, $\mathrm{n}=3$ ). DMSO, dimethyl sulfoxide; AE, aloe-emodin; SD, standard deviation.

A

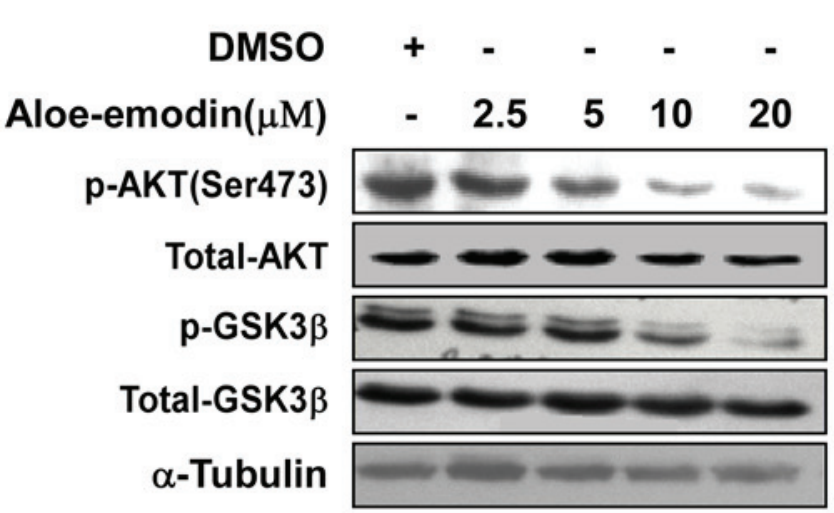

B

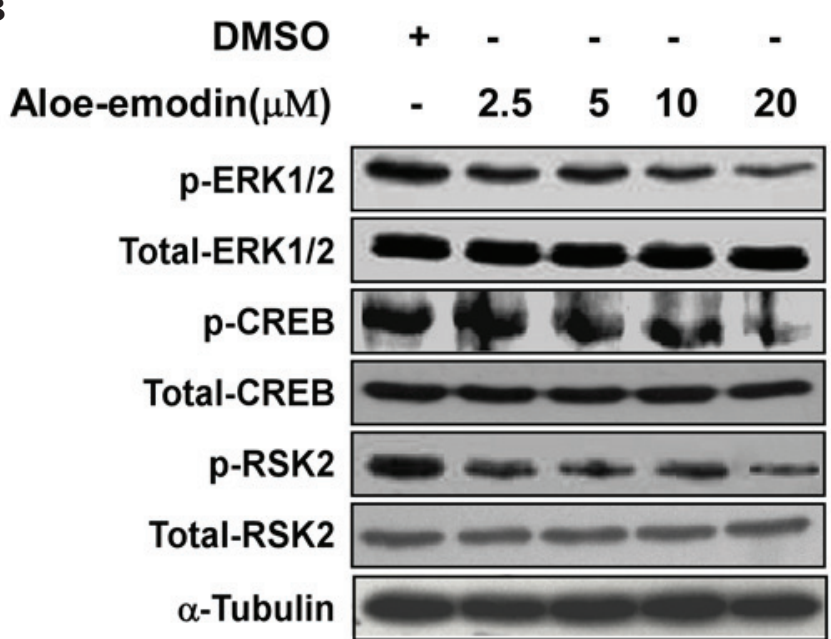

Figure 4. Aloe-emodin inhibits (A) AKT-glycogen synthase kinase $3 \beta$ and (B) extracellular-signal regulated kinase-ribosomal S6 kinase activity. Western blot analysis of TE1 cells exposed to increasing concentrations of aloe-emodin was performed. Representative data of three independent experiments are shown. DMSO, dimethyl sulfoxide; ERK, extracellular-signal regulated kinase; p-, phosphorylated; CREB, cyclic adenosine monophosphate response element-binding protein; RSK, ribosomal S6 kinase; GSK3 $\beta$, glycogen synthase kinase. 
A

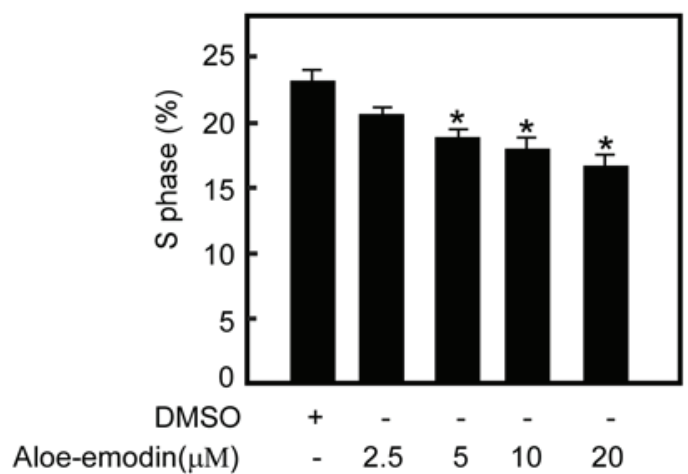

B

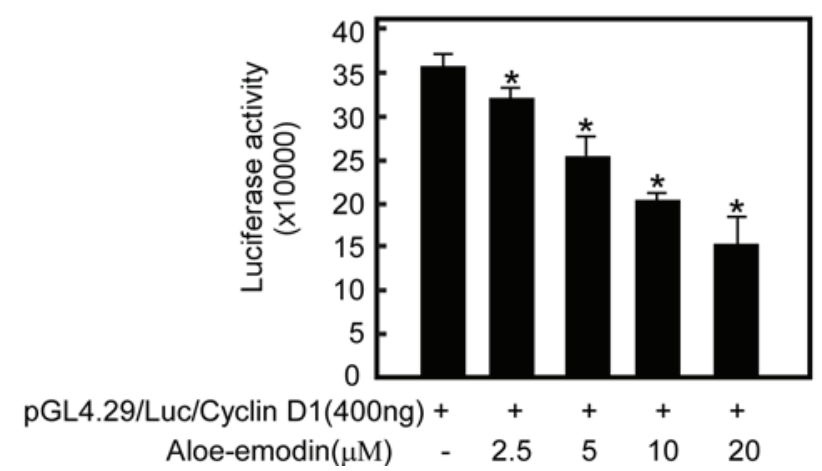

Figure 5. Aloe-emodin effects on the cell cycle. (A) Aloe-emodin significantly decreased the number of TE1 cells in S phase ( $\mathrm{P}<0.05$ vs. untreated, $\mathrm{n}=3$ ). (B) Aloe-emodin significantly inhibited cyclin D1 transcription activity in TE1 cells in a dose-dependent manner ( $\mathrm{P}<0.05$ vs. untreated, $\mathrm{n}=3)$. DMSO, dimethyl sulfoxide; Luc, luciferase.

D1 transcription, which regulates cell transition from G1 to S phase (44). To investigate the degree to which aloe-emodin-mediated $\mathrm{S}$ phase reduction is associated with cyclin expression, a cyclin D1 reporter gene assay was performed with aloe-emodin treatment. The cyclin D1 reporter gene assay demonstrated that aloe-emodin could inhibit cyclin D1 transcription activity in a dose-dependent manner (Fig. 5B).

\section{Discussion}

Signal transduction pathways have an important role in tumorigenesis (45). Both AKT and ERK are important molecules in the MEK/ERK and PI3K/AKT signal transduction pathways $(46,47)$. In the present study, ERK and AKT were activated in EC cell lines, including TE1, Eca109 and KYSE 140, which implies that these two activation pathways are important in esophageal tumorigenesis and development. Previous studies have also indicated that both MEK/ERK and PI3K/AKT signaling are activated in ESCC $(8,48,49)$. Therefore, blocking these two pathways is a promising strategy for EC treatment and chemoprevention.

Previous research on cancer cells has revealed that aloe-emodin has anti-proliferative effects and can induce apoptosis at high doses (50). Aloe-emodin suppresses prostate cancer by targeting mTORC2 and inhibiting growth in a dose-dependent manner, with a maximal inhibitory effect at a concentration of $15 \mu \mathrm{M}$ (36). By contrast, other studies have indicated that aloe-emodin has anti-proliferative effects at $75 \mu \mathrm{M}$ and induces apoptosis of human hepatoma Huh-7 cells via downregulation of calpain-2 and ubiquitin-protein ligase E3A (51). In the present study, aloe-emodin had a cytotoxic effect on EC cells. Thus, at lower doses than those previously reported $(<20 \mu \mathrm{M})$, aloe-emodin inhibited TE1 cell proliferation and anchor-independent cell growth in a dose-dependent manner. Cell cycle analysis indicated that aloe-emodin inhibited cell entry into $\mathrm{S}$ phase. These data demonstrated that aloe-emodin is a promising compound for suppressing the growth of EC cells.

Aloe-emodin has been reported to inhibit tumor cell proliferation through various mechanisms $(35,50)$. Aloe-emodin induced $\mathrm{G} 2 / \mathrm{M}$ arrest and differentiation of cervical cancer cells (52), while induced apoptosis of retina ganglion cells in glaucomatous patients through regulation of ERK phosphorylation (53). Aloe-emodin induced apoptosis, autophagy and differentiation of glioma cells by inhibiting the action of ERK (54). In the current study, aloe-emodin at low doses inhibited AKT and ERK phosphorylation, which is consistent with a previous study by the present authors on prostate cancer cells (PC3) (36). However, PTEN loss caused strong activation of AKT, which, in turn, attenuated the phospho-ERK signal. This may be the explanation for the lack of an effect of ERK (55). In the current study, GSK3 $\beta$ and RSK2, the downstream kinases of AKT, were also inhibited, as was the phosphorylation of the transcription factor CREB. This suggests that aloe-emodin can suppress the MEK/ERK and PI3K/AKT signaling pathways. However, further investigation is required to determine if this is caused by one or several targets. Furthermore, aloe-emodin inhibited cyclin D1 transcription in the present study, which may be associated with AKT and ERK pathway inhibition.

In conclusion, the present study demonstrated that AKT and ERK were activated in EC cells. Aloe-emodin suppressed EC TE1 cell proliferation through the inhibition of AKT, ERK and their downstream molecules, thus regulating cyclin D1 transcription. Further studies on aloe-emodin and its potential use as a therapeutic agent for EC should be conducted.

\section{Acknowledgements}

The present study was supported by the National Natural Science Foundation of China (Beijing, China; grant nos. 81372269 and U1304813), the Science Foundation of the Henan Province of China (Zhengzhou, China; grant nos. 112106000039, 13HASTIT022, 2011A310009, 12B310022, 13A310553 and 14A310006) and the Key Science and Technology Program of Zhengzhou City (Zhengzhou, China; grant no. 141PPTGG449).

\section{References}

1. Ghasemi-Kebria F, Roshandel G, Semnani S, Shakeri R, Khoshnia M, Naeimi-Tabiei M, Merat S and Malekzadeh R: Marked increase in the incidence rate of esophageal adenocarcinoma in a high-risk area for esophageal cancer. Arch Iran Med 16: 320-323, 2013.

2. Zhang XM and Guo MZ: The value of epigenetic markers in esophageal cancer. Front Med China 4: 378-384, 2010.

3. Jemal A, Bray F, Center MM, Ferlay J, Ward E and Forman D: Global cancer statistics. CA Cancer J Clin 61: 69-90, 2011.

4. Pohl H, Sirovich B and Welch HG: Esophageal adenocarcinoma incidence: Are we reaching the peak? Cancer Epidemiol Biomarkers Prev 19: 1468-1470, 2010. 
5. Siegel R, Naishadham D and Jemal A: Cancer statistics for Hispanics/Latinos, 2012. CA Cancer J Clin 62: 283-298, 2012.

6. Pennathur A, Gibson MK, Jobe BA and Luketich JD: Oesophageal carcinoma. Lancet 381: 400-412, 2013.

7. Pennathur A, Farkas A, Krasinskas AM, Ferson PF, Gooding WE, Gibson MK, Schuchert MJ, Landreneau RJ and Luketich JD: Esophagectomy for T1 esophageal cancer: Outcomes in 100 patients and implications for endoscopic therapy. Ann Thorac Surg 87: 1048-1054; discussion 1054-1055, 2009.

8. Akagi I, Miyashita M, Makino H, Nomura T, Hagiwara N, Takahashi K, Cho K, Mishima T, Ishibashi O, Ushijima T, et al: Overexpression of PIK3CA is associated with lymph node metastasis in esophageal squamous cell carcinoma. Int J Oncol 34: 767-775, 2009

9. Okines A, Cunningham D and Chau I: Targeting the human EGFR family in esophagogastric cancer. Nat Rev Clin Oncol 8: 492-503, 2011

10. Bettstetter M, Berezowska S, Keller G, Walch A, Feuchtinger A, Slotta-Huspenina J, Feith M, Drecoll E, Höfler H and Langer R Epidermal growth factor receptor, phosphatidylinositol-3-kinase catalytic subunit/PTEN, and KRAS/NRAS/BRAF in primary resected esophageal adenocarcinomas: Loss of PTEN is associated with worse clinical outcome. Hum Pathol 44: 829-836, 2013.

11. Hou G, Lu Z, Liu M, Liu H and Xue L: Mutational analysis of the PTEN gene and its effects in esophageal squamous cell carcinoma. Dig Dis Sci 56: 1315-1322, 2011.

12. Cho MY, Kim HS, Eng C, Kim DS, Kang SJ, Eom M, Yi SY and Bronner MP: First report of ovarian dysgerminoma in Cowden syndrome with germline PTEN mutation and PTEN-related 10q loss of tumor heterozygosity. Am J Surg Pathol 32: 1258-1264, 2008.

13. Lugli A, Zlobec I, Minoo P, Tornillo L, Terracciano L and Jass JR: Role of the mitogen-activated protein kinase and phosphoinositide 3-kinase/AKT pathways downstream molecules, phosphorylated extracellular signal-regulated kinase, and phosphorylated AKT in colorectal cancer - a tissue microarray-based approach. Hum Pathol 37: 1022-1031,2006.

14. Kocieniewski P and Lipniacki T: MEK1 and MEK2 differentially control the duration and amplitude of the ERK cascade response. Phys Biol 10: 035006, 2013.

15. Chappell WH, Steelman LS, Long JM, Kempf RC, Abrams SL, Franklin RA, Bäsecke J, Stivala F, Donia M, Fagone P, et al: Ras/Raf/MEK/ERK and PI3K/PTEN/Akt/mTOR inhibitors: Rationale and importance to inhibiting these pathways in human health. Oncotarget 2: 135-164, 2011.

16. Mebratu Y and Tesfaigzi Y: How ERK1/2 activation controls cell proliferation and cell death: Is subcellular localization the answer? Cell Cycle 8: 1168-1175, 2009.

17. Santarpia L, Lippman SM and El-Naggar AK: Targeting the MAPK-RAS-RAF signaling pathway in cancer therapy. Expert Opin Ther Targets 16: 103-119, 2012.

18. Martelli AM, Tabellini G, Bressanin D, Ognibene A, Goto K, Cocco L and Evangelisti C: The emerging multiple roles of nuclear Akt. Biochim Biophys Acta 1823: 2168-2178, 2012.

19. Li XY, Zhan XR, Liu XM and Wang XC: CREB is a regulatory target for the protein kinase Akt/PKB in the differentiation of pancreatic ductal cells into islet $\beta$-cells mediated by hepatocyte growth factor. Biochem Biophys Res Commun 404: 711-716, 2011

20. Du K and Montminy M: CREB is a regulatory target for the protein kinase Akt/PKB. J Biol Chem 273: 32377-32379, 1998

21. Nicholson KM and Anderson NG: The protein kinase B/Akt signalling pathway in human malignancy. Cell Signal 14: 381-395, 2002.

22. Wang JM, Chao JR, Chen W, Kuo ML, Yen JJ and Yang-Yen HF: The antiapoptotic gene mcl-1 is up-regulated by the phosphatidylinositol 3-kinase/Akt signaling pathway through a transcription factor complex containing CREB. Mol Cell Biol 19 6195-6206, 1999.

23. Feng J, Tamaskovic R, Yang Z, Brazil DP, Merlo A, Hess D and Hemmings BA: Stabilization of Mdm2 via decreased ubiquitination is mediated by protein kinase B/Akt-dependent phosphorylation. J Biol Chem 279: 35510-35517, 2004

24. Zhou BP, Liao Y, Xia W, Spohn B, Lee MH and Hung MC: Cytoplasmic localization of p21Cip1/WAF1 by Akt-induced phosphorylation in HER-2/neu-overexpressing cells. Nat Cell Biol 3: 245-252, 2001.

25. Diehl JA, Cheng M, Roussel MF and Sherr CJ: Glycogen synthase kinase-3beta regulates cyclin D1 proteolysis and subcellular localization. Genes Dev 12: 3499-3511, 1998.
26. Gregory MA, Qi Y and Hann SR: Phosphorylation by glycogen synthase kinase-3 controls c-myc proteolysis and subnuclear localization. J Biol Chem 278: 51606-51612, 2003.

27. Popadic D, Savic E, Ramic Z, Djordjevic V, Trajkovic V, Medenica L and Popadic S: Aloe-emodin inhibits proliferation of adult human keratinocytes in vitro. J Cosmet Sci 63: 297-302, 2012.

28. Tabolacci C, Oliverio S, Lentini A, Rossi S, Galbiati A, Montesano C, Mattioli P, Provenzano B, Facchiano F and Beninati S: Aloe-emodin as antiproliferative and differentiating agent on human U937 monoblastic leukemia cells. Life Sci 89: 812-820, 2011.

29. Suboj P, Babykutty S, Srinivas P and Gopala S: Aloe emodin induces $\mathrm{G} 2 / \mathrm{M}$ cell cycle arrest and apoptosis via activation of caspase-6 in human colon cancer cells. Pharmacology 89: 91-98, 2012.

30. Radovic J, Maksimovic-Ivanic D, Timotijevic G, Popadic S, Ramic Z, Trajkovic V, Miljkovic D, Stosic-Grujicic S and Mijatovic S: Cell-type dependent response of melanoma cells to aloe emodin. Food Chem Toxicol 50: 3181-3189, 2012

31. Pecere T, Gazzola MV, Mucignat C, Parolin C, Vecchia FD, Cavaggioni A, Basso G, Diaspro A, Salvato B, Carli M and Palù G: Aloe-emodin is a new type of anticancer agent with selective activity against neuroectodermal tumors. Cancer Res 60: 2800-2804, 2000.

32. Lin ML, Lu YC, Chung JG, Li YC, Wang SG, N G SH, Wu CY, Su HL and Chen SS: Aloe-emodin induces apoptosis of human nasopharyngeal carcinoma cells via caspase-8-mediated activation of the mitochondrial death pathway. Cancer Lett 291: 46-58, 2010.

33. Lee HZ: Protein kinase $\mathrm{C}$ involvement in aloe-emodin- and emodin-induced apoptosis in lung carcinoma cell. Br J Pharmacol 134: 1093-1103, 2001.

34. Kuo PL, Lin TC and Lin CC: The antiproliferative activity of aloe-emodin is through p53-dependent and p21-dependent apoptotic pathway in human hepatoma cell lines. Life Sci 71: 1879-1892, 2002

35. Guo J, Xiao B, Zhang S, Liu D, Liao Y and Sun Q: Growth inhibitory effects of gastric cancer cells with an increase in $\mathrm{S}$ phase and alkaline phosphatase activity repression by aloe-emodin. Cancer Biol Ther 6: 85-88, 2007.

36. Liu K, Park C, Li S, Lee KW, Liu H, He L, Soung NK, Ahn JS, Bode AM, Dong Z, et al: Aloe-emodin suppresses prostate cancer by targeting the mTOR complex 2. Carcinogenesis 33: 1406-1411, 2012

37. Lu GD, Shen HM, Chung MC and Ong CN: Critical role of oxidative stress and sustained JNK activation in aloe-emodin-mediated apoptotic cell death in human hepatoma cells. Carcinogenesis 28: 1937-1945, 2007.

38. Chiu TH, Lai WW, Hsia TC, Yang JS, Lai TY, Wu PP, Ma CY, Yeh CC, Ho CC, Lu HF, et al: Aloe-emodin induces cell death through S-phase arrest and caspase-dependent pathways in human tongue squamous cancer SCC-4 cells. Anticancer Res 29: 4503-4511, 2009.

39. Wang ZW, Wang JS, Yang MH, Luo JG and Kong LY: Developmental Changes in the composition of five anthraquinones from rheum palmatum as quantified by (1) H-NMR. Phytochem Anal 24: 329-335, 2013

40. Di Luccia B, Manzo N, Vivo M, Galano E, Amoresano A, Crescenzi E, Pollice A, Tudisco R, Infascelli F and Calabrò V: A biochemical and cellular approach to explore the antiproliferative and prodifferentiative activity of Aloe arborescens leaf extract. Phytother Res 27: 1819-1828, 2013.

41. Albanese C, Johnson J, Watanabe G, Eklund N, Vu D, Arnold A and Pestell RG: Transforming p21ras mutants and c-Ets-2 activate the cyclin D1 promoter through distinguishable regions. J Biol Chem 270: 23589-23597, 1995.

42. Guo J, Xiao B, Liu Q, Gong Z and Le Y: Suppression of C-myc expression associates with anti-proliferation of aloe-emodin on gastric cancer cells. Cancer Invest 26: 369-374, 2008.

43. Suboj P, Babykutty S, Valiyaparambil Gopi DR, Nair RS, Srinivas P and Gopala S: Aloe emodin inhibits colon cancer cell migration/angiogenesis by downregulating MMP-2/9, RhoB and VEGF via reduced DNA binding activity of NF- $\kappa$ B. Eur J Pharm Sci 45:581-591, 2012

44. Shimura T: Acquired radioresistance of cancer and the AKT/GSK3ß/cyclin D1 overexpression cycle. J Radiat Res 52: 539-544, 2011.

45. Fonar Y and Frank D: FAK and WNT signaling: The meeting of two pathways in cancer and development. Anticancer Agents Med Chem 11: 600-606, 2011. 
46. Xia $\mathrm{P}$ and $\mathrm{Xu} \mathrm{XY}$ : $\mathrm{PI} 3 \mathrm{~K} / \mathrm{Akt} / \mathrm{mTOR}$ signaling pathway in cancer stem cells: From basic research to clinical application. Am J Cancer Res 5: 1602-1609, 2015.

47. Steelman LS, Chappell WH, Abrams SL, Kempf RC, Long J, Laidler P, Mijatovic S, Maksimovic-Ivanic D, Stivala F, Mazzarino MC, et al: Roles of the Raf/MEK/ERK and $\mathrm{PI} 3 \mathrm{~K} / \mathrm{PTEN} / \mathrm{Akt} / \mathrm{mTOR}$ pathways in controlling growth and sensitivity to therapy-implications for cancer and aging. Aging (Albany NY) 3: 192-222, 2011.

48. Shigaki H, Baba Y, Watanabe M, Murata A, Ishimoto T, Iwatsuki M, Iwagami S, Nosho K and Baba H: PIK3CA mutation is associated with a favorable prognosis among patients with curatively resected esophageal squamous cell carcinoma. Clin Cancer Res 19: 2451-2459, 2013.

49. Roberts PJ and Der CJ: Targeting the Raf-MEK-ERK mitogen-activated protein kinase cascade for the treatment of cancer. Oncogene 26: 3291-3310, 2007.

50. Acevedo-Duncan M, Russell C, Patel S and Patel R: Aloe-emodin modulates PKC isozymes, inhibits proliferation, and induces apoptosis in U-373MG glioma cells. Int Immunopharmacol 4: 1775-1784, 2004.
51. Jeon W, Jeon YK and Nam MJ: Apoptosis by aloe-emodin is mediated through down-regulation of calpain-2 and ubiquitin-protein ligase E3A in human hepatoma Huh-7 cells. Cell Biol Int 36: 163-167, 2012.

52. Guo JM, Xiao BX, Liu Q, Zhang S, Liu DH and Gong ZH: Anticancer effect of aloe-emodin on cervical cancer cells involves G2/M arrest and induction of differentiation. Acta Pharmacol Sin 28: 1991-1995, 2007.

53. Lin HJ, Chao PD, Huang SY, Wan L, Wu CJ and Tsai FJ: Aloe-emodin suppressed NMDA-induced apoptosis of retinal ganglion cells through regulation of ERK phosphorylation. Phytother Res 21: 1007-1014, 2007.

54. Mijatovic S, Maksimovic-Ivanic D, Radovic J, Miljkovic Dj, Harhaji Lj, Vuckovic O, Stosic-Grujicic S, Mostarica Stojkovic M and Trajkovic V: Anti-glioma action of aloe emodin: The role of ERK inhibition. Cell Mol Life Sci 62: 589-598, 2005.

55. Selvaraj N, Budka JA, Ferris MW, Jerde TJ and Hollenhorst PC: Prostate cancer ETS rearrangements switch a cell migration gene expression program from RAS/ERK to PI3K/AKT regulation. Mol Cancer 13: 61, 2014. 